\title{
Mechanical Property Evaluation and Remaining Life Assessment of Service Exposed Steam Pipe of Boilers in a Thermal Power Plant
}

\author{
A.K. Ray, Y.N. Tiwari, R.K. Sinha, S.K. Sinha, P.K. Roy, R. Singh \\ and S. Chaudhuri \\ Materials Evaluation Division, National Metallurgical Laboratory \\ Jamshedpur-831107, India
}

\begin{abstract}
This paper is aimed at investigating the residual life of more than eleven years service exposed main steam pipes of various boilers in a thermal power plant. The remaining life assessment for safety was made using destructive accelerated stress rupture and tensile tests at different temperatures, and some non-destructive tests. There was no evidence of localised damage in the form of surface cracks, cavitation or dents in the service exposed main steam pipes of all the boilers. So far as the remaining life at $550^{\circ} \mathrm{C}$ is concerned, it is possible to obtain a life of greater than 100,000 hours, both at the allowable as well as operating hoop stress levels of the service exposed pipes, provided no localised damage in the form of cracks or dents has been developed. It is recommended that a health check should be carried out after 50,000 hours of service exposure at $550^{\circ} \mathrm{C}$.
\end{abstract}

Key Words: Service exposed, steam pipe, boilers, stress rupture test, tensile properties, residual life.

\section{INTRODUCTION}

It is widely known that carbon and Cr-Mo steels are extensively used as high temperature components in power plants /1-7/. Even though most of these components have a specific design life of 20 years, many of these are known to have survived much longer. In view of the increasing cost of setting up a new plant, there is now considerable interest in life extension of the existing units. In order to arrive at a quantitative estimate of the remaining life of such ageing components, it is necessary to have some creep and stress rupture data.

The latest studies on the design methodology and life estimation for major components for steam turbines were reviewed /3/. Relationships which enable the calculation of actual creep damage were 
clarified by many studies. Several revolutionary devices have been introduced which enable the detection of local creep and fatigue damage. Studies of life estimation of welded joints in the design stages were discussed. It was shown that the remaining life of such components can be analysed from creep and stress rupture properties by defining a reference stress such that the component life equals the life of a simple specimen tested at the reference stress. Keeping this in view, over the years attempts are being made to generate such data on similar components /4-7/.

The aim of the present work is therefore to evaluate the remaining life of more than eleven years service exposed main steam pipes of boilers, based on experimentally determined tensile and stress rupture properties of service exposed materials.

\section{MATERIAL AND HISTORY OF THE SERVICE EXPOSED MAIN STEAM PIPES OF THE BOILERS}

The material specifications, listing service conditions and history of operation of the service exposed main steam pipe of all the boilers under the same operating conditions but with different service exposures, are given in Tables $1 \mathrm{~A}$ and $\mathrm{lb}$ respectively.

\section{Table 1a}

Material Specifications and Service Conditions of the Service Exposed Main Steam Pipes

\begin{tabular}{|l|l|}
\hline Material & $1 \mathrm{Cr}-0.5 \mathrm{Mo}-0.25 \mathrm{~V}-$ Russian Graded Steel $(12 \times 1 \mathrm{M} 4)$ \\
\hline Design Stress: & $45.8 \mathrm{MPa}$ \\
\hline Operating temperature: & $550^{\circ} \mathrm{C}$ \\
\hline Allowable stress: & $65 \mathrm{MPa}$ \\
\hline Service Conditions: & \multicolumn{2}{|l}{} \\
\hline Steam pressure in the main steam pipes: & $90 \pm \mathrm{atm}$ \\
\hline Steam temperature: & $535 \pm 13^{\circ} \mathrm{C}$ \\
\hline Boiler capacity: & 240 tonnes of steam/hour \\
\hline
\end{tabular}

Table $1 \mathrm{~b}$

History of Operation

\begin{tabular}{|c|c|c|}
\hline Sl. No. & Type of Main Steam Pipe & Service Exposure (hrs) \\
\hline 1 & Boiler E & 167000 \\
\hline 2 & Boiler D & 166000 \\
\hline 3 & Boiler F & 106000 \\
\hline 4 & Boiler G & 105000 \\
\hline 5 & Boiler H & 100000 \\
\hline 6 & Boiler I & 112000 \\
\hline
\end{tabular}




\subsection{Dimension and visual examination of the pipe}

The outer diameter and length of the pipes were $273 \mathrm{~mm}$ and $450 \mathrm{~mm}$ respectively. The average wall thickness of the main steam pipes varied between $20-23 \mathrm{~mm}$. There was also no evidence of localised and general corrosion/oxidation on either external or internal surfaces of the pipes. Dimensions of the outer diameter (OD) were measured at two mutually perpendicular directions along the length of the pipe at an interval of $150 \mathrm{~mm}$.

\section{EXPERIMENTAL}

Chemical analysis as revealed in Table 2 shows that the materials in the present investigation are basically Cr-Mo steels conforming to the Russian Grade specified.

Optical metallographic examinations (Figs. 1 and 2) were carried out on the virgin, service exposed

Table 2

Chemical analysis and virgin and service exposed boilers

\begin{tabular}{|c|c|c|c|c|c|c|c|c|c|c|c|c|c|}
\hline \multirow{2}{*}{$\begin{array}{l}\text { SI. } \\
\text { No }\end{array}$} & \multirow{2}{*}{$\begin{array}{c}\text { Type of } \\
\text { Main } \\
\text { Steam Pipe }\end{array}$} & \multicolumn{12}{|c|}{ Wt \% of Elements present } \\
\hline & & $\mathrm{C}$ & $\mathrm{Mn}$ & $\mathrm{Si}$ & $S$ & $P$ & $\mathrm{~N}$ & $\mathrm{Cr}$ & Mo & $\mathrm{V}$ & $\mathrm{Ni}$ & $\mathrm{Cu}$ & $\mathrm{Sb}$ \\
\hline 1 & Virgin & 0.08 & 0.40 & 0.17 & 0.025 & 0.025 & - & 0.90 & 0.35 & 0.20 & 0.25 & 0.20 & - \\
\hline 2 & Boiler D & 0.10 & 0.50 & 0.25 & 0.011 & 0.007 & $=$ & 1.11 & 0.25 & 0.23 & - & $=$ & - \\
\hline 3 & Boiler E & 0.12 & 0.56 & 0.28 & 0.011 & 0.007 & - & 1.11 & 0.22 & 0.22 & - & - & - \\
\hline 4 & Boiler $F$ & 0.10 & 0.54 & 0.24 & 0.012 & 0.008 &. & 1.12 & 0.27 & 0.23 & - & - & - \\
\hline 5 & Boiler $\mathrm{G}$ & 0.06 & 0.56 & $0 / 25$ & 0.011 & 0.007 & - & 1.13 & 0.27 & 0.24 & - & - & - \\
\hline 6 & Boiler $\mathrm{H}$ & 0.08 & 0.61 & 0.26 & 0.033 & 0.013 & - & 1.25 & 0.22 & 0.29 & - & -- & - \\
\hline 7 & Boiler I & 0.08 & 0.61 & 0.26 & 0.033 & 0.013 & - & 1.25 & 0.22 & 0.29 & - & - & - \\
\hline
\end{tabular}

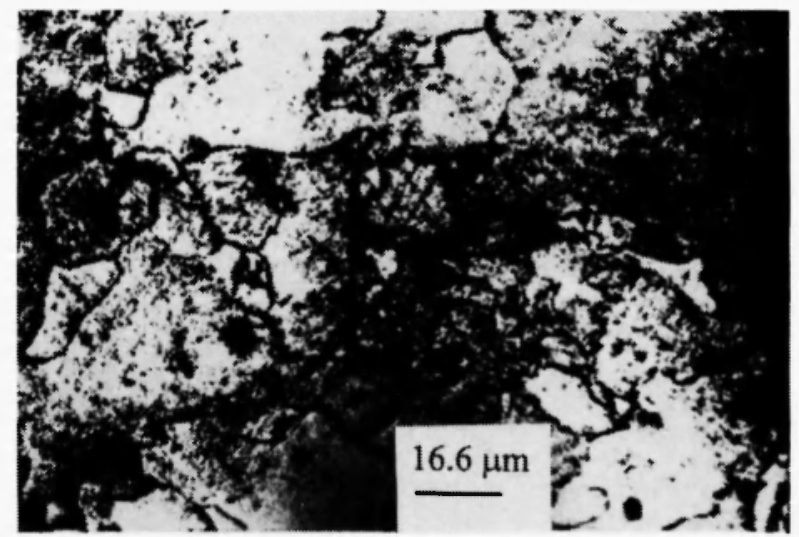

Fig. 1: Optical micrograph of the virgin pipe at $\times 600$, revealing ferrite grains dispersed with carbides. There is no evidence of graphitization and creep damage in the form of cavities and decarburization. 


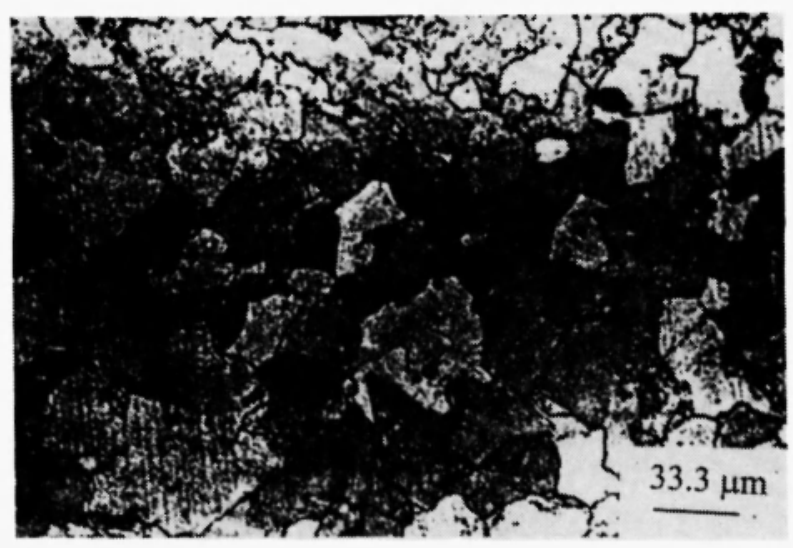

Fig. 2: A typical optical micrograph of service exposed main steam pipe of boilers at $\times 300$, revealing ferrite grains dispersed with carbides. There is no evidence of graphitization and creep damage in the form of cavities and decarburization. This photomicrograph is for boiler $D$.

Table 3

Hardness values of the virgin and service exposed main steam pipes

\begin{tabular}{|c|c|c|}
\hline SI.No & $\begin{array}{l}\text { Type of main steam } \\
\text { pipe }\end{array}$ & $\begin{array}{c}\text { Hardness Value } \\
\text { (VHN) }\end{array}$ \\
\hline 1 & Virgin & 153 \\
\hline 2 & Boiler D & 143 \\
\hline 3 & Boiler E & 149 \\
\hline 4 & Boiler F & 145 \\
\hline 5 & Boiler G & 150 \\
\hline 6 & Boiler H & 151 \\
\hline 7 & Boiler I & 142 \\
\hline
\end{tabular}

main steam pipes of all boilers (D, E, F, G, I and H). The hardness values in the base for boilers are shown in Table 3.

Tensile tests at room temperature, $350^{\circ} \mathrm{C}, 400^{\circ} \mathrm{C}, 450^{\circ} \mathrm{C}, 500^{\circ} \mathrm{C}, 550^{\circ} \mathrm{C}, 600^{\circ} \mathrm{C}$ and $650^{\circ} \mathrm{C}$ of the service exposed base metal were performed using a digitally controlled 8562 Instron servo-electric testing system, equipped with a 3-zone split furnace with PID control. Standard tensile specimens were made from the service exposed materials as per ASTM E8-79 specification. Tensile tests were carried out on the base only from the longitudinal direction of the main steam pipes of the service exposed boilers. During tensile testing, constant test temperature of $\pm 2{ }^{\circ} \mathrm{C}$ and a constant displacement rate of \pm $0.2 \mathrm{~mm} / \mathrm{min}$ were maintained. The variation of the Yield Strength $(0.2 \%$ Proof Stress $)$ and Ultimate Tensile Strength (UTS) with temperature of testing is shown in Figs. $3 a$ and $3 b$. Figures $3 c$ and $3 d$ show the variation of \% RA (reduction in area) and \% EL (elongation) with temperature of testing respectively. 


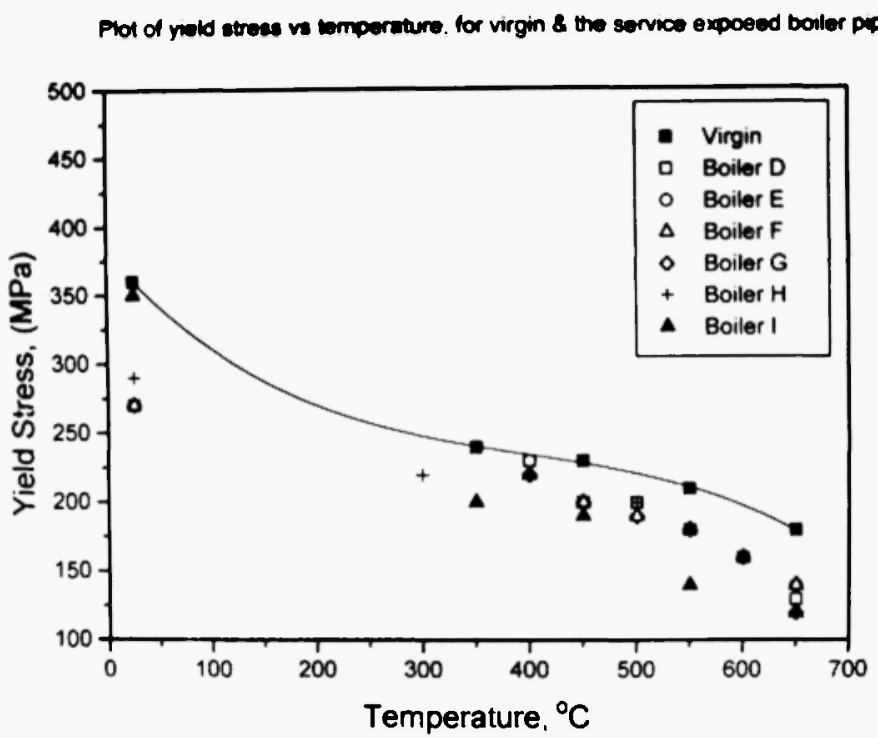

Fig. 3a: Plot of yield strength ( $0.2 \%$ proof stress) vs test temperature for virgin and service exposed boiler pipes.

Plot of ultimate tensile strength vs temperature for virgin \& service exposed boiler pipes

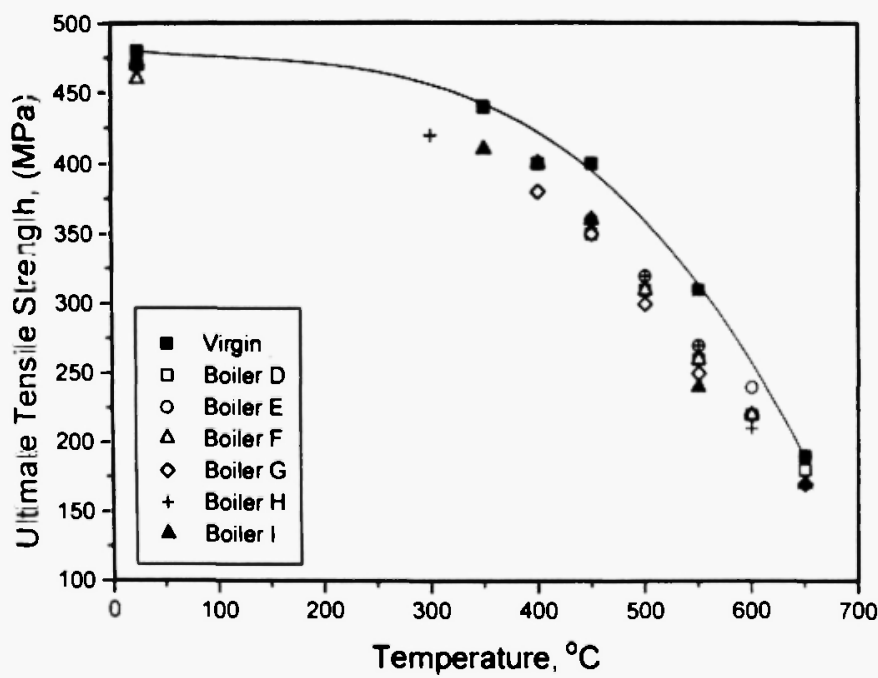

Fig. 3b: Plot of ultimate tensile strength (UTS) vs test temperature for virgin and service exposed boiler pipes. 


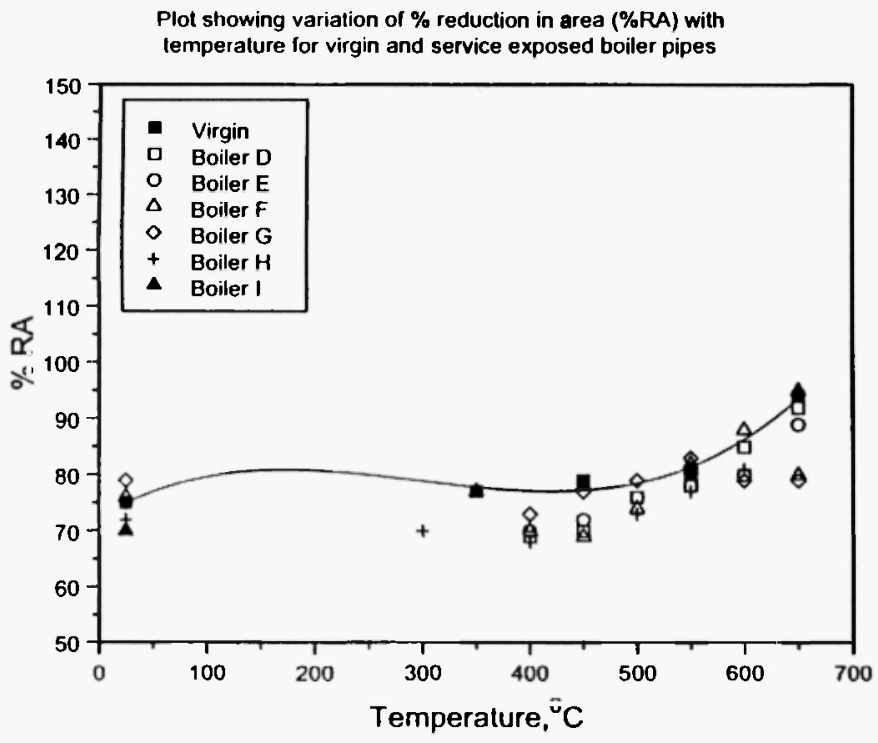

Fig. 3c: Plot showing variation of \% reduction in area (\%RA) with test temperature for virgin and service exposed boiler pipes.

plot of \% EL. (elongation) vs temperature for virgin and service exposed pipes

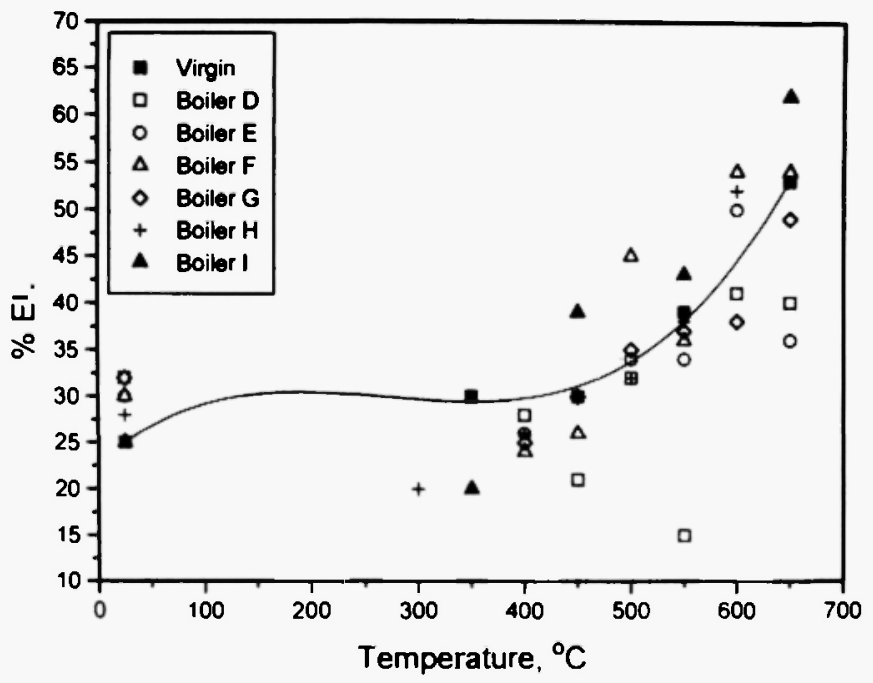

Fig. 3d: Plot showing variation of \% elongation (\%EL) with test temperature for virgin and service exposed boiler pipes. 
The hoop stress $\sigma_{h}$ acting on the service exposed pipes was calculated using the following formula to predict the remaining life:

$$
\sigma_{h}=P D / 2 t
$$

where $P$ is the operating pressure in $\mathrm{MPa}, D$ is the mean diameter in $\mathrm{mm}$ and $t$ is the thickness of the pipe in $\mathrm{mm}$. The operating hoop stresses for the different main steam pipes of boilers $\mathrm{D}, \mathrm{E}$ and $\mathrm{F}$ as evaluated from the above formula were $52.1 \mathrm{MPa}, 50 \mathrm{MPa}$ and $58 \mathrm{MPa}$ respectively. Incidentally, the operating hoop stresses for boilers $\mathrm{H}$ and I were the same as that for boiler $\mathrm{E}$. Also the operating hoop stress for the main steam pipe of boiler $G$ was the same as that of boiler $F$.

Although the design stress and operating temperature were $45.8 \mathrm{MPa}$ and $550^{\circ} \mathrm{C}$ respectively, it was decided that the accelerated stress rupture tests to be carried out in the range of $525^{\circ} \mathrm{C}$ to $690^{\circ} \mathrm{C}$ and the lives were evaluated at $65 \mathrm{MPa}$, since the allowable stress level of the boilers is $65 \mathrm{MPa}$. Accelerated stress rupture tests using Mayes creep testing machines were carried out as per ASTM 139/83 specification with specimens made from the chordal direction of the main steam pipe of each boiler. These tests were carried out at various stress levels in the range of 65-200 MPa for the virgin pipe and 65-190 $\mathrm{MPa}$ for the service exposed steam pipes, to generate data with high extrapolation capability. The stress levels above the operating hoop stress at each temperature were selected in such a way as to obtain rupture within a reasonable span of time.

The generation of stress rupture data was carried out in two ways.

a) Increased temperature tests: At a constant stress of $65 \mathrm{MPa}$, acceleration was achieved by increasing the test temperature above the specified service temperature which is about $550^{\circ} \mathrm{C}$. The range of temperature selected for the tests for various service exposed main steam pipes varied from $525^{\circ} \mathrm{C}$ to $690^{\circ} \mathrm{C}$. To generate more meaningful stress rupture data for life prediction methodology, stress levels even beyond $65 \mathrm{MPa}$ (allowable stress) to a maximum of $190 \mathrm{MPa}$ were selected.

b) Increased stress test: Acceleration was achieved by increasing the stress level beyond $65 \mathrm{MPa}$ which is the allowable stress level specified. Keeping the temperature constant at $550^{\circ} \mathrm{C}$, the stress levels selected for these tests were in the range 110-190 MPa.

The stress rupture data under the above stipulated conditions of acceleration are given in Table 4.

The rupture data for the specimens have been plotted in terms of $\log$ (stress) vs Larson-Miller Parameter $\{\mathrm{LMP}=T(20+\log t r)\}$, where $T$ is the absolute temperature in ${ }^{\circ} \mathrm{K}$ and $t r$ is the rupture time in hours. For the purpose of comparison, the best fit curve using third order polynomial for the virgin pipe has been superimposed on this plot. Regression analysis of stress rupture data for virgin as well as service exposed main steam pipes has been carried out using a standard software package, in order to evaluate the long term rupture strength of the components over a range of temperatures. 
Vol. 12, No. l, 200I

Mechanical Property Evaluation and Remaining Life Assessment of Service Exposed Steam Pipe of Boilers in a Thermal Power Plant

Table 4

Stress rupture properties of virgin and service exposed boiler pipes

\begin{tabular}{|c|c|c|c|c|c|c|}
\hline Material & $\begin{array}{c}\text { Sl } \\
\text { No }\end{array}$ & $\begin{array}{c}\text { Test } \\
\text { Temp } \\
\text { ("C) }\end{array}$ & $\begin{array}{l}\text { Stress } \\
\text { (Mpa) }\end{array}$ & $\begin{array}{c}\text { Rupture } \\
\text { Time } \\
\text { (hrs) }\end{array}$ & $\% \mathbf{E L}$ & $\%$ RA \\
\hline \multirow[t]{6}{*}{ Virgin (Increased stress test) } & 1 & 550 & 200 & 46 & 32 & 56 \\
\hline & 2 & 550 & 180 & 205 & 36 & 54 \\
\hline & 3 & 550 & 150 & 960 & 36 & 56 \\
\hline & 4 & 550 & 140 & 1440 & 25 & 71 \\
\hline & 5 & 550 & 130 & 6048 & Interrupted & - \\
\hline & 6 & 550 & 120 & 11088 & Interrupted & - \\
\hline \multirow[t]{5}{*}{ Virgin (Increased temperature test) } & 1 & 690 & 65 & 77 & 13 & 71 \\
\hline & 2 & 670 & 65 & 218 & 17 & 85 \\
\hline & 3 & 650 & 65 & 672 & 15 & 80 \\
\hline & 4 & 630 & 65 & 1673 & 10 & 18 \\
\hline & 5 & 610 & 65 & 5032 & 10 & 210 \\
\hline \multirow[t]{14}{*}{ Boiler D (Increased stress test) } & 1 & 525 & 180 & 170 & 53 & 80 \\
\hline & 2 & 525 & 170 & 441 & 47 & 79 \\
\hline & 3 & 525 & 160 & 432 & 54 & 80 \\
\hline & 4 & 525 & 140 & 2688 & 53 & 72 \\
\hline & 1 & 550 & 160 & 70 & 53 & 77 \\
\hline & 2 & 550 & 150 & 242 & 52 & 77 \\
\hline & 3 & 550 & 140 & 730 & 51 & 75 \\
\hline & 4 & 550 & 130 & 1739 & 54 & 7.7 \\
\hline & 5 & 550 & 110 & 5352 & 24 & 47 \\
\hline & 1 & 600 & 120 & 121 & 58 & 80 \\
\hline & 2 & 600 & 110 & 912 & 45 & 67 \\
\hline & 3 & 600 & 100 & 1656 & 17 & 53 \\
\hline & 4 & 600 & 90 & 2544 & 27 & 42 \\
\hline & 5 & 600 & 80 & 5352 & 16 & 50 \\
\hline \multirow[t]{3}{*}{ Boiler D (Increased temperature test) } & 1 & 670 & 65 & 466 & 43 & 51 \\
\hline & 2 & 650 & 70 & 610 & 38 & 44 \\
\hline & 3 & 630 & 75 & 2696 & 31 & 51 \\
\hline \multirow[t]{14}{*}{ Boiler E (Increased stress test) } & 1 & $\overline{525}$ & 180 & 178 & $\overline{54}$ & 82 \\
\hline & 2 & 525 & 170 & 533 & 55 & 82 \\
\hline & 3 & 525 & 160 & 264 & 53 & 77 \\
\hline & 4 & 525 & 140 & 1512 & 55 & 82 \\
\hline & 1 & 550 & 160 & 103 & 56 & 80 \\
\hline & 2 & 550 & 150 & 270 & 48 & 77 \\
\hline & 3 & 550 & 140 & 462 & 38 & 83 \\
\hline & 4 & 550 & 130 & 4104 & 35 & 65 \\
\hline & 5 & 550 & 110 & 6216 & 45 & 76 \\
\hline & 1 & 600 & 120 & 216 & 51 & 71 \\
\hline & 2 & 600 & 110 & 556 & 27 & 77 \\
\hline & 3 & 600 & 100 & 1288 & 27 & 67 \\
\hline & 4 & 600 & 90 & 3905 & 42 & 71 \\
\hline & 5 & 600 & 80 & 6672 & Interrupted & - \\
\hline
\end{tabular}


Table 4 (continued)

Stress rupture properties of virgin and service exposed boiler pipes

\begin{tabular}{|c|c|c|c|c|c|c|}
\hline Material & $\begin{array}{c}\text { Sl } \\
\text { No }\end{array}$ & $\begin{array}{c}\text { Test } \\
\text { Temp } \\
\text { ("C) } \\
\end{array}$ & $\begin{array}{l}\text { Stress } \\
\text { (MPa) }\end{array}$ & $\begin{array}{c}\text { Rupture } \\
\text { Time } \\
\text { (hrs) }\end{array}$ & $\% \mathrm{EL}$ & $\%$ RA \\
\hline \multirow[t]{3}{*}{ Boiler E (Increased temperature test) } & 1 & 670 & 65 & 269 & 49 & 88 \\
\hline & 2 & 650 & 70 & 740 & 52 & 88 \\
\hline & 3. & 630 & 75 & 2940 & 44 & 84 \\
\hline \multirow{13}{*}{ Boiler F (Increased stress test) } & 1 & 550 & 110 & 11232 & Interrupted & - \\
\hline & 2 & 550 & 130 & 1728 & 48 & 67 \\
\hline & 3 & 550 & 140 & 658 & 46 & 68 \\
\hline & 4 & 550 & 150 & 254 & 81 & 76 \\
\hline & 5 & 550 & 160 & 54 & 49 & 74 \\
\hline & 1 & 525 & 160 & 304 & 55 & 79 \\
\hline & 2 & 525 & 170 & 284 & 48 & 76 \\
\hline & 3 & 525 & 180 & 187 & 48 & 76 \\
\hline & 1 & 600 & 80 & 4296 & 8 & 22 \\
\hline & 2 & 600 & 90 & 2736 & 11 & 44 \\
\hline & 3 & 600 & 100 & 928 & 30 & 44 \\
\hline & 4 & 600 & 110 & 504 & 39 & 47 \\
\hline & 5 & 600 & 120 & 238 & 50 & 49 \\
\hline \multirow{3}{*}{ Boiler F (Increased temperature test) } & 1 & 630 & 75 & 2952 & 18 & 36 \\
\hline & 2 & 650 & 70 & 648 & 28 & 56 \\
\hline & 3 & 670 & 65 & 418 & 17 & 28 \\
\hline \multirow[t]{14}{*}{ Boiler G (Increased stress test) } & 1 & 550 & 110 & 6936 & 47 & 71 \\
\hline & 2 & 550 & 130 & 744 & 55 & 71 \\
\hline & 3 & 550 & 140 & 432 & 40 & 7.9 \\
\hline & $4^{\circ}$ & 550 & 150 & 161 & 25 & 56 \\
\hline & 5 & 550 & 160 & 32 & 57 & 77 \\
\hline & I & 525 & 140 & 864 & 52 & 74 \\
\hline & 2 & 525 & 160 & 264 & 53 & 77 \\
\hline & 3 & 525 & 170 & 163 & 59 & 76 \\
\hline & 4 & 525 & 180 & 120 & 52 & 77 \\
\hline & 1 & 600 & 80 & 5616 & 08 & 39 \\
\hline & 2 & 600 & 90 & 1512 & 28 & 38 \\
\hline & 3 & 600 & 100 & 672 & 38 & 48 \\
\hline & 4 & 600 & 110 & 462 & 32 & 59 \\
\hline & 5 & 600 & 120 & 76 & 58 & 67 \\
\hline \multirow{3}{*}{$\begin{array}{l}\text { Boiler } G \text { (Increased temperature } \\
\text { test) }\end{array}$} & I & 630 & 75 & 2769 & 20 & 44 \\
\hline & 2 & 650 & 70 & 768 & 24 & 44 \\
\hline & 3 & 670 & 65 & 336 & 32 & 48 \\
\hline
\end{tabular}


Table 4 (continued)

Stress rupture properties of virgin and service exposed boiler pipes

\begin{tabular}{|l|c|c|c|c|c|c|}
\hline \multicolumn{1}{|c|}{ Material } & $\begin{array}{c}\text { SI } \\
\text { No }\end{array}$ & $\begin{array}{c}\text { Test } \\
\text { Temp } \\
\text { ("C) }\end{array}$ & $\begin{array}{c}\text { Stress } \\
(\mathbf{M P a})\end{array}$ & $\begin{array}{c}\text { Rupture } \\
\text { Time } \\
\text { (hrs) }\end{array}$ & \% EL & \% RA \\
\hline Boiler H (Increased stress test) & 1 & 550 & 190 & 24 & 23 & 78 \\
& 2 & 550 & 170 & 97 & 39 & 98 \\
& 3 & 550 & 150 & 264 & 37 & 75 \\
& 4 & 550 & 130 & 993 & 39 & 78 \\
& 5 & 550 & 110 & 5137 & 40 & 80 \\
Boiler H (Increased temperature & 6 & 550 & 90 & 9182 & Interrupted & \\
test) & 1 & 690 & 65 & 18 & 45 & 89 \\
& 2 & 670 & 65 & 198 & 38 & 79 \\
& 3 & 650 & 65 & 686 & 13 & 44 \\
& 4 & 630 & 65 & 1602 & 22 & 33 \\
& 5 & 610 & 65 & 5236 & 30 & 40 \\
\hline Boiler I (Increased stress test) & 1 & 550 & 190 & 04 & 26 & 79 \\
& 2 & 550 & 170 & 69 & 38 & 84 \\
& 3 & 550 & 150 & 89 & 76 & 84 \\
& 4 & 550 & 120 & 1539 & 48 & 87 \\
& 5 & 550 & 100 & 5724 & 49 & 85 \\
& 1 & 690 & 65 & 39 & 63 & 80 \\
& 2 & 670 & 65 & 54 & 52 & 88 \\
& 3 & 650 & 65 & 312 & 33 & 78 \\
& 4 & 630 & 65 & 321 & 34 & 77 \\
& 5 & 610 & 65 & 2021 & 35 & 78 \\
& 6 & 600 & 65 & 4150 & Interrupted \\
& & & & & & \\
\hline
\end{tabular}

The Larson-Miller Parameter $(L M P)=T(C+\log t r)=a_{0}+a_{l}(\log S)+a_{2}(\log S)^{2}+a_{m}(\log S)^{m}$

where $T=$ Temperature in ${ }^{\circ} \mathrm{K}$

tr $=$ Rupture time in hrs

$S$ - Rupture strength in $\mathrm{MPa}$

$m=$ Order of polynomial

$C=20$

$m, a_{10}, a_{l}, a_{2}$ and $a_{3}$ are polynomial constants, Table 5 shows the rupture strengths $(S)$ of the service exposed pipes for various rupture times and at $m=3$. 
Table 5

Estimated rupture strength in $\mathrm{MPa}$

\begin{tabular}{|c|c|c|c|c|c|}
\hline \multirow{2}{*}{$\begin{array}{l}\text { Type of main } \\
\text { steam pipe }\end{array}$} & \multirow{2}{*}{$\begin{array}{c}\text { Order of } \\
\text { polynomial }\end{array}$} & \multirow{2}{*}{$\begin{array}{c}\text { Temperature, } \\
{ }^{\circ} \mathrm{C}\end{array}$} & \multicolumn{3}{|c|}{ Time, hrs } \\
\hline & & & $\operatorname{tr}=10,000$ & $\operatorname{tr}=30,000$ & $\operatorname{tr}=100,000$ \\
\hline Virgin & $m=3 ; C=20$ & $\begin{array}{c}550 \\
500 \\
-\end{array}$ & $\begin{array}{l}108 \\
119 \\
-\end{array}$ & $\begin{array}{c}93.00 \\
103.00 \\
-\end{array}$ & $\begin{array}{c}78.70 \\
86 \\
-\end{array}$ \\
\hline Boiler D & $m=3 ; C=20$ & $\begin{array}{l}500 \\
525 \\
550 \\
575 \\
\end{array}$ & $\begin{array}{c}142 \\
123 \\
106 \\
89 \\
\end{array}$ & $\begin{array}{c}128 \\
110 \\
93 \\
76\end{array}$ & $\begin{array}{c}115 \\
97 \\
79 \\
62\end{array}$ \\
\hline Boiler E & $m=3 ; C=20$ & $\begin{array}{l}500 \\
525 \\
550 \\
575 \\
\end{array}$ & $\begin{array}{l}143 \\
125 \\
107 \\
89 \\
\end{array}$ & $\begin{array}{c}130 \\
112 \\
94 \\
76 \\
\end{array}$ & $\begin{array}{c}116 \\
100 \\
79 \\
60\end{array}$ \\
\hline Boiler F & $m=3 ; C=20$ & $\begin{array}{l}500 \\
525 \\
550 \\
600 \\
\end{array}$ & $\begin{array}{c}144 \\
125 \\
108 \\
74 \\
\end{array}$ & $\begin{array}{c}131 \\
113 \\
96 \\
59\end{array}$ & $\begin{array}{c}119 \\
100 \\
83 \\
-\end{array}$ \\
\hline Boiler G & $\mathrm{m}=3 ; \mathrm{C}=20$ & $\begin{array}{l}500 \\
525 \\
550 \\
600\end{array}$ & $\begin{array}{c}138 \\
120 \\
103 \\
88\end{array}$ & $\begin{array}{c}127 \\
109 \\
92 \\
77\end{array}$ & $\begin{array}{l}114 \\
97 \\
81 \\
67\end{array}$ \\
\hline Boiler $\mathrm{H}$ & $\mathrm{m}=3 ; \mathrm{C}=20$ & $\begin{array}{l}550 \\
550 \\
550 \\
\end{array}$ & $\begin{array}{r}96 \\
99 \\
91 \\
\end{array}$ & $\begin{array}{l}84 \\
86 \\
79 \\
\end{array}$ & $\begin{array}{l}72 \\
73 \\
70 \\
\end{array}$ \\
\hline Boiler I & $m=3 ; C=20$ & $\begin{array}{l}500 \\
525 \\
550 \\
575 \\
\end{array}$ & $\begin{array}{c}123 \\
106 \\
91 \\
78 \\
\end{array}$ & $\begin{array}{c}110 \\
95 \\
81 \\
70 \\
\end{array}$ & $\begin{array}{c}98 \\
84 \\
72 \\
6 \\
\end{array}$ \\
\hline
\end{tabular}

\section{RESULTS AND DISCUSSION}

\subsection{Visual observation and metallography}

Dimensional measurement revealed that there was no change in outer diameter and thickness of the service exposed pipes. It seems that the pipes have not undergone any appreciable deformation during actual operating conditions. Any evidence of localised and general corrosion/oxidation was not observed on either external or internal surfaces. The hardness level of the virgin and service exposed main steam pipe of various boilers revealed (see Table 3) no significant variation in hardness values with exposure lives.

The microstructure of the virgin material mainly consisted of ferrite grains dispersed with carbides 
(Fig. 1). A typical micrograph of service exposed main steam pipes is shown in Fig. 2. Evidence of graphitization and creep damage in the form of cavitation and decarburisation was not observed in any of the service exposed main steam pipes. Therefore, it is clear that the virgin as well as those of the service exposed main steam pipes of all the boilers have had hardly any appreciable degradation from the microstructural point of view.

\subsection{Mechanical properties}

Room temperature as well as high temperature tensile properties as obtained from experiments are reported, Fig. 3. It is evident from the results that $0.2 \%$ proof stress (yield strength) and the UTS (ultimate tensile strength) values for the service exposed pipes showed a decreasing trend with increasing temperature. However, \% RA (reduction in area) and \% EL (elongation) showed an increasing trend with temperature. This is the common trend observed for materials tested at elevated temperature $/ 12,13 /$. Analysis of tensile data revealed that there is some deterioration in yield stress ( $0.2 \%$ proof stress), ultimate tensile strengths (see Figs. 3a and 3b), \% RA and \% EL (see Figs. 3c and 3d) of the service exposed main steam pipes of all the boilers compared to those of the virgin pipe, due to service exposure. However, these variations fall within the specified limits for a similar grade of steels, viz. $1 \mathrm{Cr}-\frac{1}{2} \mathrm{Mo}-02.5 \mathrm{~V}$ steels, as reported in the literature $/ 12 /$.

In the absence of discernible cavitation or flaws, stress rupture tests can be used selectively to assess the condition of components. One of the most widely used techniques for life assessment of components involves removal of samples and conducting accelerated tests at temperatures above the service temperature 18 . An estimate of the remaining life is then made by extrapolation of the results to the service temperature. Several uncertainties relating to the validity and application of the technique have been resolved in recent research projects $/ 8 \%$.

In the present investigation, long term rupture strengths were estimated with best fitted curves for third order polynomial. For different orders of the polynomial, the average sum square error (ASSE) was estimated from the following equation:

$$
A S S E=\Sigma\left(Y_{\text {xpperimental }}-Y_{\text {estimated }}\right)^{2} / n
$$

where $n$ is the number of data points. The third order polynomial was selected for estimation of rupture strength as there was no significant change in the average sum square error for higher orders.

Analysis of rupture data clearly indicates that the properties of the present steel are closely comparable to those of the virgin pipe (Fig. 4), suggesting no appreciable creep damage. The data points of the stress vs. LMP plots (Fig. 4) for all the service exposed materials fall within the $\pm 20 \%$ scatter band of the virgin material. The best fit curve for the virgin material has been extrapolated to a lower stress value beyond $65 \mathrm{MPa}$ which is the allowable stress level of the service exposed main steam pipes of all boilers, for the purpose of life prediction (Fig. 4). Previous investigators $19,10 /$ have 
Plot of stress vs Larson-Miller parameter (LMP) for various boilers and virgin pipe

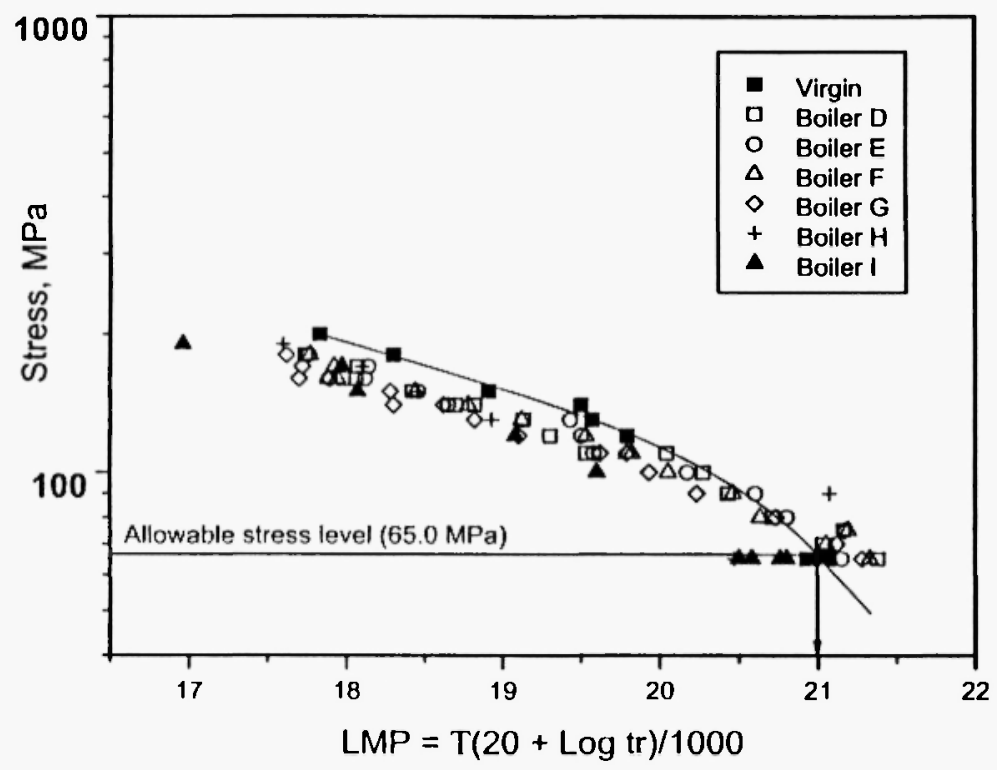

Fig. 4: Plot of stress vs Larson-Miller Parameter (LMP) for virgin as well as service exposed boiler pipes.

estimated the remaining life of such ageing components by comparing the upper limit of the data scatter band in stress rupture tests with the ASTM and BSS mean data line. However, for life prediction in the present investigation, it was found that superimposition of ISO-206 mean data line does not aid discussion on the influence of service exposure on the main steam pipe of the boilers. Therefore the experimental data for the virgin pipe was superimposed on the service exposed data for the boilers for the purpose of comparison and life prediction of the service exposed pipes. At higher stress levels, creep rupture data fall outside the $-20 \%$ scatter band limit of the virgin pipe which is indicative of creep properties inferior to the standard material. On the other hand, at low stresses, the experimental data for the service exposed boilers approaches that of the virgin material (Fig. 4). This is a typical trend that is observed with service exposed material. At low stress levels, the service exposed main steam pipes of some of the boilers have superior stress rupture properties compared to that of the virgin pipe (see Fig. 4). In fact it is seen from Fig. 4 that at the allowable stress and operating hoop stress levels, the life of boilers $\mathrm{D}, \mathrm{E}$ and $\mathrm{F}$ is even greater than that of the virgin material. This is mainly because stress rupture data usually exhibit a wide scatter of about $\pm 20 \%$ around the mean data. A minor variation in chemical composition and section size of the test specimen may have a significant influence on rupture lives $/ 12,13$. At lower stress levels, scatter is even higher, as reported in the literature $/ 12,13 /$. Hence a slightly higher residual life of some of the boilers $D, E$ and $F$, as estimated in the present investigation, is not unusual. 
The remaining lives of all the service exposed main steam pipes of all the boilers predicted at 65 $\mathrm{MPa}$ and at $550^{\circ} \mathrm{C}$ are shown in Fig. 4. At this stress level for all the service exposed pipes, the LMP value as read from the plot of stress vs LMP (Fig. 4) is about 21000 . Nevertheless, at the respective operating hoop stress level for various boilers, the LMP values as read from Fig. 4 varied between 21150 to 21300 . At this value of LMP, one would expect a very long life. As a rule, an inspection life of $>100,000$ hours is recommended.

Since it is not always possible to give the precise residual life in view of some uncertainties, including the over extrapolation, it should also be the practice to make use of the following criteria to decide the serviceability (see Fig. 5) of such service exposed components /11/:

a) Time margin $\quad=t_{f} / t_{s}>3$

b) Stress margin $=\sigma_{\text {creep }} / \sigma_{s}>1.00$
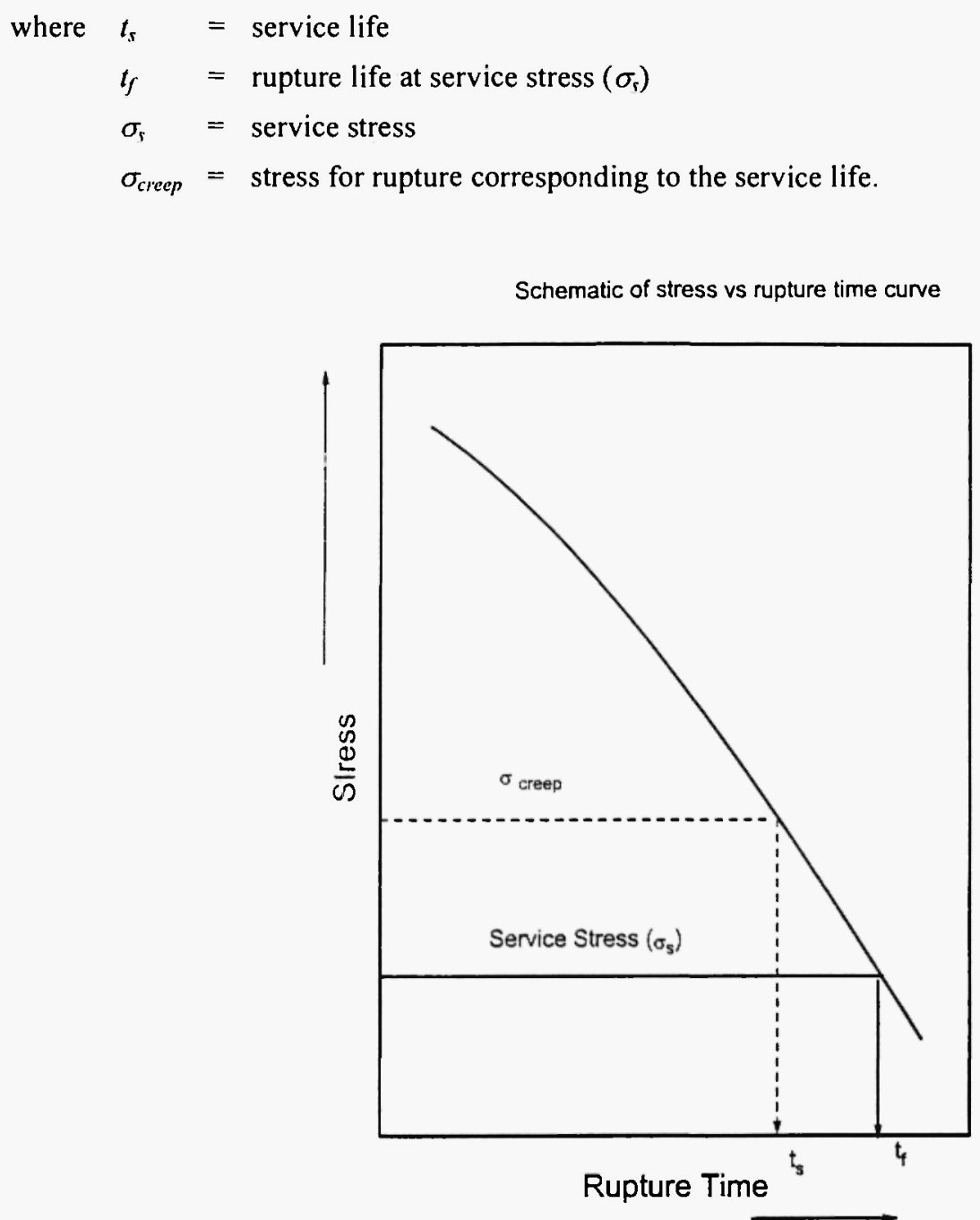

Fig. 5: Schematic of stress vs rupture plot. 
Table 6

Stress and time margin at $550^{\circ} \mathrm{C}$

\begin{tabular}{|c|c|c|c|c|}
\hline $\begin{array}{c}\text { Type of Main } \\
\text { Steam Pipe }\end{array}$ & $\begin{array}{c}\text { Stress Margin at } \\
\text { Operating hoop } \\
\text { stress levels }\end{array}$ & $\begin{array}{c}\text { Stress Margin at } \\
\text { Allowable stress } \\
\text { level }(65 \mathrm{MPa})\end{array}$ & $\begin{array}{c}\text { Time Margin at } \\
\text { operating hoop } \\
\text { stress levels }\end{array}$ & $\begin{array}{c}\text { Time Margin at } \\
\text { allowable stress } \\
\text { level (65 MPa) }\end{array}$ \\
\hline Virgin & - & - & - & - \\
\hline Boiler D & 1.14 & 1.41 & 5.12 & 6.05 \\
\hline Boiler E & 1.09 & 1.41 & 5.4 & 3.44 \\
\hline Boiler F & 1.27 & 1.41 & 5.58 & 7.17 \\
\hline Boiler G & 1.26 & 1.41 & 5.63 & 6.30 \\
\hline Boiler H & 1.09 & 1.41 & 8.9 & 3.99 \\
\hline Boiler I & 1.09 & 1.41 & 8.03 & 3.56 \\
\hline
\end{tabular}

The higher the time margin, the better is the safety of operation for the service exposed materials. The values of the above margins as estimated from the stress rupture data in the present investigation for service exposed main steam pipes of boilers are displayed in Table 6.

So far as the remaining life at $550^{\circ} \mathrm{C} / 65 \mathrm{MPa}$ is concerned, it is possible to obtain a minimum life of $>100,000$ hours for the service exposed main steam pipes provided there is no evidence of localised damage in the form of surface cracks, cavitation or dents. Another check for safety of the service exposed pipes in terms of residual life is recommended to be carried out after expiry of 50,000 hours of service life for reasons of economy and safety. Also, during shut down of the plant, NDT (nondestructive) tests, viz. dimensional (thickness and diameter) measurement, hardness measurement and in situ metallography may be carried out to assess the condition of the materials for their future serviceability. NDT examination of the weld joints at regular intervals during operation is desirable as the microstructural examination of the welding in some cases revealed the presence of defects like microporosities.

\section{CONCLUSIONS}

This study leads to the following conclusions:

i) So far as the residual life at $550^{\circ} \mathrm{C}$ is concerned, it is possible to obtain a minimum life of about 100,000 hours for the service exposed main steam pipes provided there is no evidence of localised damage in the form of surface cracks, cavitation or dents.

ii) Analysis of tensile data revealed that there is some deterioration in yield stress $0.2 \%$ proof stress), ultimate tensile strength, \% RA and \%EL of the service exposed main steam pipes of all the boilers compared to those of the virgin pipe, but these variations are within the specific limits for similar grades of steels, as reported in the literature. 
iii) The service exposed main steam pipes of all the boilers appear to be in a reasonably good state of health. Another check for safety of the service exposed pipes in terms of residual life is recommended to be carried out after expiry of 50,000 hours of service for economical and safety reasons. Also during shut down of the plant, NDT (non-destructive) tests, viz. dimensional (thickness and diameter) measurement, hardness measurement and in situ metallography may be carried out to assess the condition of the materials for their future serviceability. NDT examination of the weld joints at regular intervals during shut down is desirable, as the microstructural examination of the welding in some cases revealed the presence of defects like microporosities.

\section{ACKNOWLEDGEMENT}

The authors are grateful to Prof. P. Ramachandra Rao - Director, National Metallurgical Laboratory, Jamshedpur, India, for his kind permission to publish this paper.

\section{REFERENCES}

1. D. D'Angelo and A. Percivate, in: Proceedings of International Conference on Creep, Tokyo, Japan, 14-18 April, 1986.

2. I.A. Klevtsov and Kh.A. Tallermo, Teploenergetika, 12, 21 (1996).

3. T. Endo, Int. J. Press. Vess. and Piping, 57(1), 7 (1994).

4. M. de Witte, Int. J. Press. Vess. and Piping, 39, (1-2), 41 (1996).

5. Y.D. Li, Int. J. Press. Vess. and Piping, 69 (2), 161 (1996).

6. I. Klevtsov, H. Tallermo and R.A. Crane, in: Proceedings of International Conference on Plant Condition and Life Measurement, Vol. I. Helsinki, Finland, 6 - 8 June, 1995; Publ. Technical Research Centre of Finland.

7. B. Wilshire, Int. J. Press. Vess. and Piping, 39 (1-2), 73 (1989).

8. R. Viswanathan, R. Dooley and A. Saxena, in: Proceedings of International Conference on Life Assessment and Extension, Vol. II, Congress Centre, The Hague, The Netherlands, 13-15 June, 1988; p. 175.

9. A.K. Singh, A.J. Bagdasarian and V.K. Malhotra, in NACE International, Houston, TX, USA, 1994; p. 21.

10. I.W. Goodall and R.A. Ainsworth, CEGB Res., 16, 34 (1984).

11. J. Gabriel, [[initials]l Vanderschaeghe and G. Vigneron, in: Proceedings of International Conference on Life Assessment and Extension, Vol. II, Congress Centre, The Hague, The Netherlands, 13-15 June, 1988; p. 136. 
12. Data sheets on the elevated-temperature properties of $1 \mathrm{Cr}-1 \mathrm{Mo}-0.25 \mathrm{~V}$ steel castings for steam turbine castings (ASTM A356/A356 M-9), NRIM creep data sheet, No. 3IB, 1994.

13.S. Chaudhuri, Some aspects of creep behaviour of $2.25 \mathrm{Cr}$-lMo steel, Ph.D. Thesis, I.I.T. Kharagpur, 1993. 
